\title{
Biodegradation of Pesticide Chlorpyrifos by Bacteria Staphylococcus aureus (Accession no. CP023500.1) Isolated from Agricultural Soil
}

\author{
Sonal Suman ${ }^{1}$, Tanuja Singh ${ }^{2 *}$, Satyamvada Swayamprabha ${ }^{3}$ and Shivanand Singh ${ }^{4}$ \\ 'Department of Biotechnology, Magadh University, Bodh Gaya - 824234, Bihar, India \\ 2Department of Biotechnology and Botany, TPS College, Patna - 800001, Bihar, India; tanujapatnabotany@gmail.com \\ ${ }^{3}$ Department of Biochemistry, Magadh University, Bodh Gaya - 824234, Bihar, India \\ ${ }^{4}$ Department of Zoology, Babasaheb Bhimrao Ambedkar Bihar University, Muzaffarapur - 842002, Bihar, India
}

\begin{abstract}
The use of pesticides like Chlorpyrifos in agricultural soil is the primary reason for the pollution of aquatic and terrestrial environments. Today the most effective method used for bioremediation are by using microbes. Different pesticide degrading bacteria were isolated and identified by the mean of cultural, biochemical tests and which is further identified and confirmed by 16S RNA sequencing method. The most potent strain S-1 growth in mineral salt medium supplemented with Chlorpyrifos as sole source of carbon (50 to $1000 \mathrm{ug} / \mathrm{ml}$ ) its optical density was measured at $600 \mathrm{~nm}$. The bacterial growth is optimised on the parameter of different physiochemical condition were. The result showed that $S$. aureus shows maximum growth on $12^{\text {th }}$ day. The HPLC analysis was also done for calculating the residual percentage of Chlorpyrifos after 12 days incubation which showed that S. aureus was able to degrade $99 \%$ of the pesticide of the $1000 \mathrm{ug} / \mathrm{ml} \mathrm{CP}$ concentration in the MSM. The results of this research shows that the isolated bacteria have the potential to be used in bioremediation of Chlorpyrifos contaminated soil and water ecosystems.
\end{abstract}

Keywords: Bacterial, Bioremediation, Chlorpyrifos, Degradation, Pesticide

\section{Introduction}

The $70 \%$ of total population of India is dependent on the agricultural primarily which is the maximum portion of the country's economy ${ }^{1}$. Pesticides are varied and large group of substances used for killing the harmful organisms like weeds, insects, rodents among others. The extensive use of such pesticides results in the accumulation of pesticide in our atmosphere. Many of these pesticides can persist in the soil and they can also contaminate the surface and the ground-water. The Organophosphate (OP) insecticides like Chlorpyrifos insecticide is also widely used and can lead to contamination of soil and water bodies. This pesticide is having a broadspectrum range and it is extensively used in the prevention of agricultural pests and it is moderately toxic insecticide. In the environment the Chlorpyrifos has been reported as having from 10 to 120 days of half-life in various soil and major degraded non-toxic end product is 3,5,6-trichloro-2-pyridinol (TCP). The high-level of the end product like TCP don't support the growth and the proliferation of soil-microorganism capable of degrading the Chlorpyrifos. The microorganism having the potential to degrade the pesticide are capable of releasing the metabolic enzyme in the soil helping in bioremediation of many anthropogenic chemicals ${ }^{2}$. Bacteria with the capability to utilise the pesticide organophosphate have been isolated and characterized from the soil all over the world ${ }^{3}$, Pseudomonas aeruginosa isolated from the soil is the gram negative bacteria and is the most common bacteria with the potential to degrade Chlorpyrifos ${ }^{4}$. In the present study the pesticide Chlorpyrifos is taken for bioremediation under different physiochemical conditions. The main objectives of this present study are to isolate the contaminated soil bacterial strains and further to characterize its Chlorpyrifos degradation potential in the MSM consisting of Chlorpyrifos as an only source of carbon in different concentrations and other environmental and chemical factors.

\section{Materials and Methodology}

\subsection{Chemicals}

All highest purity grade chemicals were used and obtained from the HiMedia, Merck and Qualigens.

${ }^{*}$ Author for correspondence 


\subsection{Sample Collection}

Agricultural soil were taken from different area of Patna, Bihar which have for the past few years had exposure history of Chlorpyrifos were selected for this study. Samples were collected randomly from three rice fields and three other crops fields from $12-15 \mathrm{~cm}$ depth of the field and stored aseptically for further analysis.

\subsection{Isolation of Chlorpyrifos Degrading Bacteria}

For isolation of microbes from different soil samples serial dilution were carried out by dissolving $0.1 \mathrm{~g}$ of each soil samples in $9.9 \mathrm{ml}$ of normal saline solution.

For isolation of bacteria $1 \mathrm{ml}$ of soil suspension of different samples were spread over the pre sterilized petriplates containing nutrient agar media at dilution $10^{-5}, 10^{-6}$ and $10^{-7}$ and further the plates were incubated at ambient temperature of $37^{\circ} \mathrm{C}$ for $24-48 \mathrm{hrs}$.

The enrichment nutrient culture media technique was used for isolation of the Chlorpyrifos utilizing microbes present in the soil samples, in which the pesticide Chlorpyrifos is used as a only carbon source in different concentration. This was done by sub-culturing those pure cultures of bacteria and fungi on pesticides containing NA media plates and incubated at $37^{\circ} \mathrm{C}$ for bacterial plates 5 .

\subsection{Characterisation and Identification of Isolates}

The isolated bacterial obtained on the Chlorpyrifos agar solid plate were further characterised by different biochemical tests like; gram staining, citrate utilization, catalase test, citrate utilization, sugar fermentation, oxidase test, motility, VogesProskeur test, methyl-red test, nitrate reduction, starch hydrolysis and hydrogen sulphide production. The purified bacterial culture were identified according to the Gerhard et al. and then using Bergey's Manual of Determinative Bacteriology for confirmation ${ }^{6}$.

The best selected strain with maximum degradation ability was further confirmed as per the result of 16s rRNA sequencing at Yaazh Xenomics (Madurai, Tamil Nadu, India). The phylogenic neighbor-joining tree was using complete $16 \mathrm{~S}$ rRNA gene sequence analysis.

\subsection{Biochemical Tests}

Some biochemical tests were conducted to show the ability of the isolates to produce enzymes such as catalase, oxidase, coagulase etc. Tests were conducted to check their ability to utilize citrate, reduce nitrate, produce indole etc. in addition to methylene red tests ${ }^{7}$.

\subsection{Effects of Various Physico-chemical Parameters}

Several physical and chemical parameters were used for optimizing the isolated bacterial growth which includes: Incubation temperature, $\mathrm{pH}$, salt concentration, carbonsource availability, nitrogen source, affecting bacterial-growth were considered ${ }^{8}$.

\subsection{Growth Kinetic of Bacterial Isolates at Different Concentration of Compounds}

Growth curve experiments were performed with different doses of Chlorpyrifos compounds in order to determine the optimum concentration of that stimulates the growth of isolates in liquid medium at different concentration (i.e. 200 $\mu \mathrm{g} / \mathrm{ml}, 250 \mu \mathrm{g} / \mathrm{ml}, 500 \mu \mathrm{g} / \mathrm{ml}$ and $1000 \mu \mathrm{g} / \mathrm{ml}$ ) of at interval of 2, 4, 8, 12 and 14 days using spectrophotometer (Rani et al. 2008). After incubating at optimum condition, the Chlroprifos (CP) the degradation and residual percentage of $\mathrm{CP}$ was calculated by using HPLC analysis?

\section{Results}

\subsection{Isolation and Characterization of Chlroprifos (CP) Degrading Bacteria}

From the agricultural soil, the bacterial cultures were isolated on by the help of MSM containing CP in different concentration (50 to $1000 \mathrm{ug} / \mathrm{ml}$ ). 35 different bacterial cultures were obtained from different soil sample. After initial screen 15 with good potential of degradation of CP were selected for further study, in which the strain S-1 was selected as the best degrader strain and shows higher degradation at $1000 \mathrm{ug} / \mathrm{ml}$ of $\mathrm{CP}$ concentration.

\subsection{Cultural and Biochemical Characteristics of the Selected Isolate}

The bacteria strain, S-1 on solid NA (Nutrient Agar) plate shows yellow colour, smooth and circular with regular margins as shown in (Figure 1). Its microscope view and the gram's staining shows it as coccus in cluster and gram-positive, coccus in cluster (Figure 2). The biochemical tests performed on the isolate showed the positive results for catalase, citrate, coagulase, sucrose and glucose fermentation with no gas formation and MR tests. As per the Bergey's Manual of Systematic Bacteriology (Gerhard et al., (1981)), the strain S-1 was identified up to the genus level as Staphyloccus species and it was further confirmed by the help of $16 \mathrm{~S}$ rRNA sequencing, as Staphylococcus aureus (Accession no. CP023500.1) at Yaazh Xenomics, Madurai, Tamil Nadu (India) with an Accession No. CP023500.1. The phylogenetic Neighbor-Joining tree 
(Figure 3) was constructed for strain S-1 using an almost complete $16 \mathrm{~S}$ rRNA gene sequence (784 bp).

By using NCBI blast similarity search tool the 16s rRNA sequence was constructed. The MUSCLE 3.7 program was further used for the multiple alignments of sequences ${ }^{10}$ which was further cured by using Gblocks 0.91 b. in to a aligned sequence $^{11}$. The program PhyML 3.0 aLRT was used for

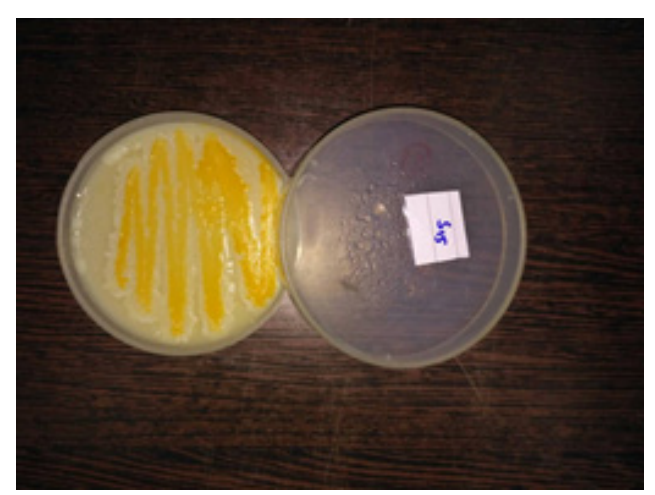

Figure 1. Coloney characteristics on NA plate

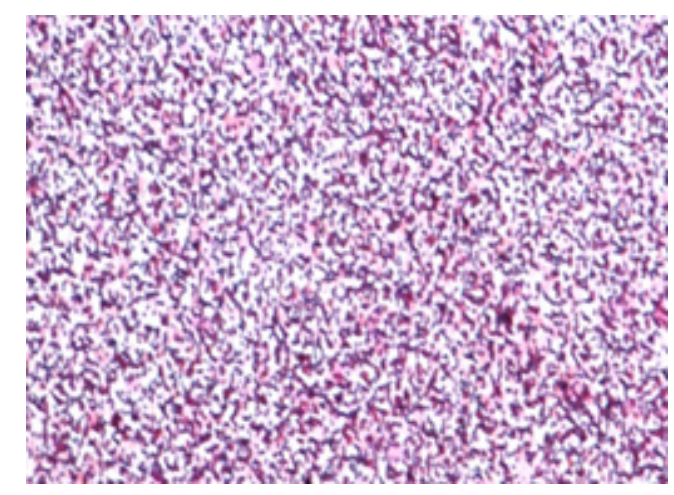

Figure 2. Microscopic view (under $40 \mathrm{X}$ ). phylogeny analysis and HKY85 as Substitution model and the programmed Tree Dyn 198.3 was used for tree construction ${ }^{12}$.

\subsection{Effect of Different Physiochemical Parameters on Growth of Isolate $\mathrm{S} 1 \mathrm{Ph}$, Temperature, $\mathrm{NaCl}$, Carbon and Nitrogen Concentration)}

To optimise the further physical and chemical characteristics the selected bacteria culture was subjected to different environmental condition like $\mathrm{pH}(3-10)$, temperature $\left(6-50^{\circ} \mathrm{C}\right)$ and $\mathrm{NaCl}$ concentrations (1-10\%), Carbon source like Glucose, Lactose, and Sucrose (1 to $5 \%$ ) and Nitrogen source like Peptone, Yeast extract, Beef extract and Casein (1 to $5 \%$ ). The observations show that S-1 (S. aureus) can tolerate a wide range of $\mathrm{pH}$ from low acidic to highly alkaline condition which shows its $\mathrm{pH}$ adaptability with the best growth at $\mathrm{pH}$ 6-7. It was also found that the $\mathrm{S} 1$ was able to survive well even at high temperature of $50^{\circ} \mathrm{C}$ and also shows tolerance to wide temperature range from $6-50^{\circ} \mathrm{C}$, with the best growth at $37^{\circ} \mathrm{C}$, it was observed that the growth was further restricted at higher temperatures from $50^{\circ} \mathrm{C}$ onwards. The tolerance range of halophytic environment condition is also found of wide range and the $\mathrm{S}-1$ was capable of growing from the range of 1-20\% NaCl concentrations and the isolate was found to highly halophytic in nature and was able to grow even at high concentration of $20 \%$ of $\mathrm{NaCl}$. The data are presented in (Table 1). Among the different carbon source the shows its best growth in the presence glucose at 5\% (Table 2) and Yeast extract as best Nitrogen source (1\%) as shown in (Table 3). As reported the soil in the India varies largely in its proprieties like from acidic to alkaline through neutral, salinity and other properties. The study and degradation potential of the

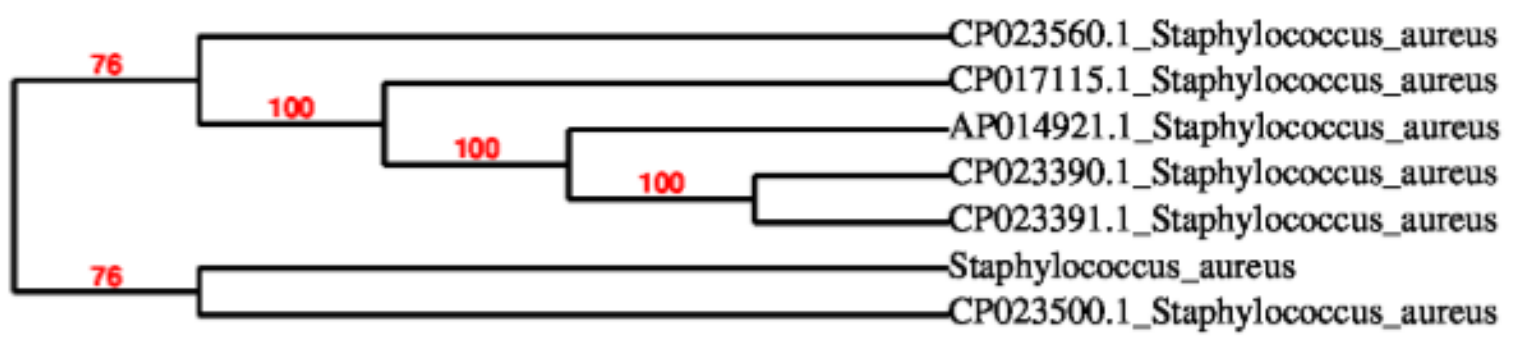

TTACGCTGCTTCGTTATACGACTTTGTTTTTCTCTCAGATTCTGCTCCTCTACCTACTA ATCGCTCTCTGTGTGATCTAAACTTGGAGGTGCTAAAAAAATAAATAGTGCATCTGG AAATTTCTTTCTAACTTTCTTTGCACCCTCTACTTCAATTTCTAAAAATACATCGAGAC CTTCGTCCATTGTATCTTTATATATTGAACTGGTGTACCGTAACATTTGCCTACATAT TCAGCGAATTCCATGACTTGGTCATCTTTGATTAAAGCTTCAAACGCATTCCTTTTTT TAAAAAAGTAATCTACATCAACTTCATCATCTTCAAGTTGTTGTGGTGTTATTGTTGA AAAAGAATTATTAGATGAAGTTGTTGCATCATCAAATCATCTTTTTACAACACTACTC CTTAC

Figure 3. Phylogenic analysis of strain S-1 based on 16s r RNA analysis. The sequence bar equals 0.02 changes per nucleotide position. 
Table 1. Effect of different environmental condition in growth of isolates $\mathrm{S}-1$

\begin{tabular}{|c|c|c|c|c|c|}
\hline $\mathrm{pH}$ & Growth & Temperature & Growth & $\mathrm{NaCl} \%$ & Growth \\
\hline 3 & - & 6 & ++ & 1 & ++ \\
\hline 4 & ++ & 12 & ++ & 5 & +++ \\
\hline 6.5 & +++ & 27 & ++ & 10 & ++ \\
\hline 10 & ++ & 37 & +++ & 15 & ++ \\
\hline 12 & - & 50 & ++ & 20 & ++ \\
\hline
\end{tabular}

Table 2. Effect of different carbon source on growth of isolates $\mathrm{S}-1$

\begin{tabular}{|c|c|c|c|}
\hline Concentration & Glucose & Lactose & Sucrose \\
\hline $1 \%$ & ++ & +++ & - \\
\hline $2 \%$ & +++ & +++ & ++ \\
\hline $3 \%$ & ++ & +++ & ++ \\
\hline $4 \%$ & ++ & ++ & ++ \\
\hline $5 \%$ & +++ & ++ & ++ \\
\hline
\end{tabular}

strain having high salinity and $\mathrm{pH}$ tolerance will help in the bioremediation study of Indian soil.

\subsection{Growth Response of Staphylococcus aureus and HPLC Analysis}

The selected strain S1 was subjected to different concentration of CP (50 to $1000 \mathrm{ug} / \mathrm{ml}$ ) as sole source of Carbon in MSM media for different time interval. The growth kinetics shows that the isolated was able to degrade the CP even at higher concentration as $1000 \mathrm{ug} / \mathrm{ml}$ and (Figure 4) shows that the isolate uses the $\mathrm{CP}$ as the sole energy and carbon-source. The best growth of S. aureus was reported on the 12 days of incubation.
Table 3. Effect of different nitrogen source on growth of isolates $\mathrm{S}-1$

\begin{tabular}{|c|c|c|c|c|}
\hline Concentration & $\begin{array}{c}\text { Yeast } \\
\text { Extract }\end{array}$ & $\begin{array}{c}\text { Beef } \\
\text { extract }\end{array}$ & Peptone & Casein \\
\hline $1 \%$ & +++ & - & ++ & - \\
\hline $2 \%$ & +++ & ++ & +++ & - \\
\hline $3 \%$ & +++ & ++ & +++ & ++ \\
\hline $4 \%$ & ++ & ++ & ++ & - \\
\hline $5 \%$ & ++ & ++ & ++ & - \\
\hline
\end{tabular}

“- = No growth, $++=$ moderate growth, $+++=$ luxuriant growth, initial medium $\mathrm{pH}$ 7."

By the HPLC-analysis, the degradation percentage was reported of the strain S-1, the chromatograms of the degraded pesticides are shown in (Figure 5). The reduction percentage and the Chlorpyrifos concentration are reported in (Table 4). High degradation percentage of $99 \%$ was achieved.

\section{Discussion}

The results obtained in this study were found in the agreement with the previous reports which shows that the degradation of Chlorpyrifos was observed at 30 where as in our result culture is capable of growing at wide range of temperature however most luxuriant was 30 to $37{ }^{\circ} \mathrm{C} .{ }^{13}$. It was reported that the optimum physical and chemical condition plays an import role in accelerating the degradation of Chlorpyrifos ${ }^{14}$. It was reported that the bacteria like Sphingomonas sp. have the potential to use Chlorpyrifos as a carbon and energy sole source for its growth, by breaking down the Chlorpyrifos into the simple compund 3,5,6-trichloro-2-pyridinol ${ }^{15}$.

Many authors reported that the most species specially the Gram negative bacteria, like Enterobacteriaceae sp. have the property to degradation of insecticides like Chlorpyrifos, but

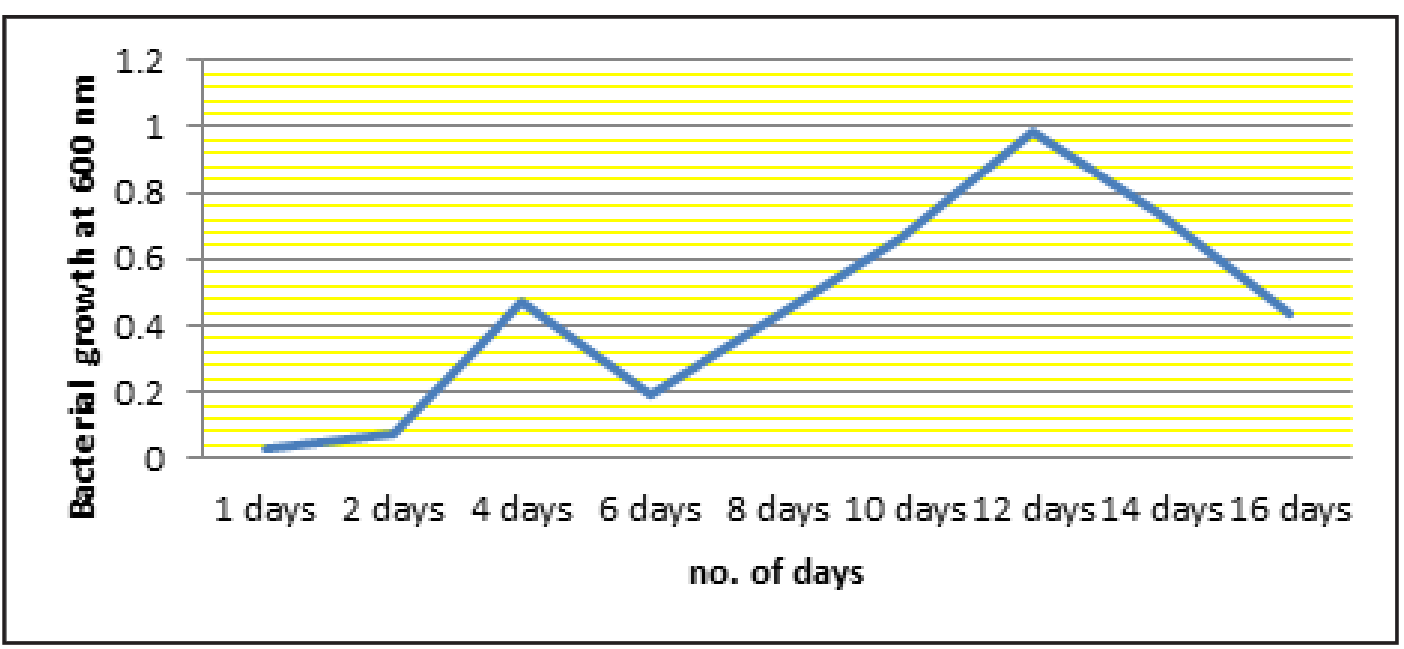

Figure 4. Growth kinetics of isolates S-1 at concentration of $1000 \mathrm{ug} / \mathrm{ml}$. 
Table 4. Degradation of CP by isolate $\mathrm{S} 1$

\begin{tabular}{|c|c|c|c|c|c|c|}
\hline Code & $\begin{array}{l}\text { Spike Sample } \\
(\mu \mathrm{g} / \mathrm{ml})\end{array}$ & $\begin{array}{l}\text { Dilution } \\
\text { Factor (DF) }\end{array}$ & $\begin{array}{l}\text { HPLC area of } \\
\text { dillution }\end{array}$ & $\begin{array}{l}\text { Concentration of dilution } \\
\text { found }(\mu \mathrm{g} / \mathrm{ml})\end{array}$ & $\begin{array}{l}\text { Concentration of } \\
\text { Sample }\left(C^{\star} \mathrm{DF}\right)\end{array}$ & \% Degraded \\
\hline S1 & 1000 & 1 & 396820 & 0.960430466 & 0.960430466 & 99.90 (approx.) \\
\hline
\end{tabular}

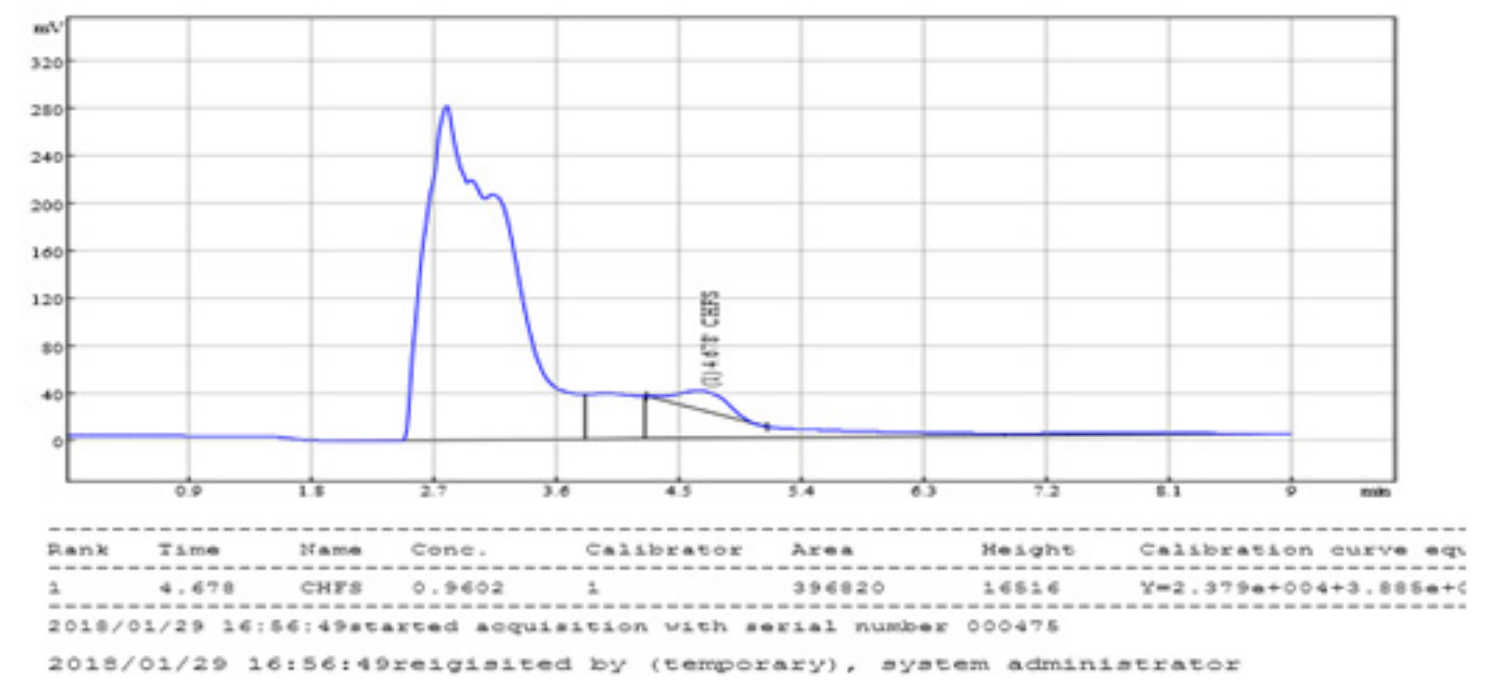

Figure 5. HPLC chromatogram of CP after degradation by S-1.

many other reports also shows that the many gram negative bacteria have the property of degradation the pesticide but they show the degradation upto only $60 \%$. Many degrader bacteria present in the soil were reported with the capability to degrade the pesticides, among all the bacteria Pseudomonas aeruginosa was the most common reported bacteria strain, it is a gram negative bacterium present in the soil and is also have the potential to utilise the Chlorpyrifos, other CP degrading reported bacteria are Providencia sp Serratia sp, Bacillus sp and Klebsiella sp, capable of degradation of Chlorpyrifos ${ }^{16,17}$.

The Chlorpyrifos degradation percentage was also reported in other studies like the rate of degradation of Chlorpyrifos by bacteria Alcaligenes faecalis DSP3 was approx $76.2 \%$ in the MSM maintained at $\mathrm{pH} 7$ and temperature $30^{\circ} \mathrm{C}$ for around 18 days. The further study also reports the isolates like Bacillus pumilus $\mathrm{C} 2 \mathrm{~A} 1$ with degradation with the degradation potential of around $89 \%$ of $1000 \mathrm{mg} \mathrm{l-1}$ in around 15 day $^{18}$. As per result obtained in our study the degradation percentage is as high as $99 \%$ and the isolate S-1 also show ability to grow in vast range of physiochemical condition.

\section{Conclusion}

The results obtained in our study shows that bacterial isolates is having a very important role in the bio-degradation of pesticides with the potential of bio-remediation. In this study S1 is having the potential of degrading the pesticide CP and using it as a energy and carbon source. The selected strain
S-1 was further identified and characterization as a highly halophylic in nature and can tolerate wide range of $\mathrm{pH}$ also. The bioremediation and degradation of the toxic pesticides by mean of bacteria is one of the most successful and effective method of preventing environmental pollution. The result of our study shows that the isolates Staphylococcus aureus is having high degradation potential and can convert upto $99 \%$ of Chlorpyrifos from the medium and have a high potential of bioremediation of Chlorpyrifos from the contaminated agricultural soil or other contaminated environment.

\section{References}

1. Sachdeva S. Pesticides and their socio-economic impact on agriculture. South. Econ. 2007; 41(38):42-53. https://doi. org/10.1016/j.seps.2005.04.002

2. Fulekar MH. UGC major research project development of bioremediation technology for pesticide industrial wastes using novel cow dung microorganisms in sequence biological reactor and two phase partitioning bioreactor. 2008.

3. Chang TC, Chang HC, Yu FW, Leni D, Mario V, Chung T. Species level identification of isolates of the Acinetobacter calcoaceticus Acinetobacter baumanni complex by sequence analysis of the 16523SrRNA gene spacer region. JClin Microbiol.2005;43(4):1632-9. PMid: 15814977 PMCid: PMC1081347. https://doi.org/10.1128/ JCM.43.4.1632-1639.2005

4. Geetha M, Fulekar MH. Bioremediation of pesticides in surface soil treatment unit using microbial consortia. Afr J Environ Sci Technol. 2008; 2(2):36-45. 
5. Zhu J, Zhao Y, Qiu J. Isolation and application of a Chlorpyrifosdegrading Bacillus licheniformis ZHU-1. Afr J Microbiol Res. 2010; 4:2410-3.

6. Buchanna RE, Gibbons NE. Bergey's manual of determinative bacteriology. 8th ed. Baltimore: Williams and Wilkins; 1984.

7. Aneja KR. Experiments in microbiology, plant pathology and biotechnology. Fourth ed. New Age International Limited. 2013.

8. Alexander M. Biodegradation and bioremediation. ed. 2 M. Alexander. San Diego: Academic Press; 1999.

9. Yang T, Ren L, Jia Y, Fan S, Wang J, Wang J, Nahurira R, Wang $\mathrm{H}$, Yan Y. Biodegradation of Di-(2-ethylhexyl) Phthalate by Rhodococcus ruber YC-YT1 in contaminated water and soil. Int Journal of Environ Re. Public Health. 2018. p. 15-35. PMid: 29751654 PMCid: PMC5982003. https://doi.org/10.3390/ ijerph15050964

10. Edgar RC. MUSCLE: Multiple sequence alignment with high accuracy and high throughput. Nucleic Acids Res. 2004; 32(5):1792-7. PMid: 15034147 PMCid: PMC390337. https://doi.org/10.1093/nar/gkh340

11. Talavera G, Castresana J. Improvement of phylogenies after removing divergent and ambiguously aligned blocks from protein sequence alignments. Systematic Biology. 2007; 56:564-77. PMid: 17654362. https://doi.org/10.1080/10635150701472164

12. Dereeper A, Guignon V, Blanc G, Audic S, Buffet S, Chevenet F, Dufayard JF, Guindon S, Lefort V, Lescot M, Claverie JM, Gascuel O. Phylogeny.f r: robust phylogenetic analysis for the non-specialist. Nucleic Acids Res. 2008. p. 1:36. PMid: 18424797 PMCid: PMC2447785. https://doi.org/10.1093/nar/gkn180

13. Singh BK, Walker A, Morgan JAW, Wright DJ. Biodegradation of Chlorpyrifos by Enterobacter strain B-14 and its use in biodegradation of contaminated soils. Applied and Environmental Microbiology. 2004; 70:4855-63. PMid: 15294824 PMCid: PMC492451. https://doi.org/10.1128/AEM.70.8.4855-4863.2004

14. Vijayalakshmi P, Usha MS. Optimization of Chlorpyrifos degradation by Pseudomonas putida. J Chem Pharm. 2012; 4:2532-9.

15. Li X, He J, Li S. Isolation of Chlorpyrifos-degrading bacterium, Sphingomonas sp. strain Dsp-2 and cloning of the mpd gene. Research in Microbiology. 2007; 158:143-9. PMid: 17306510. https://doi.org/10.1016/j.resmic.2006.11.007

16. Fulekar MH. Bioremediation technologies for environment. Indian J Environ Protect. 2005; 25(4):358-64.

17. Rani SM, Lakshim KV, Devi SP, Madlian F, Aruna K. Isolation and characterization of Chlorpyrifos degrading bacteria from agricultural soil and its growth response. African Journal of Microbiology. 2008; 2:26-31.

18. Anwar S, Liaquat F, Khan QM, Khalid ZM, Iqbal S. Biodegradation of Chlorpyrifos and its hydrolysis product 3,5,6- trichloro-2pyridinol by Bacillus pumilus strain C2A1. J. Hazard. Mater. 2009; 168(1):400-5. PMid: 19297093. https://doi.org/10.1016/j. jhazmat.2009.02.059 